\title{
PROJECT REPORT
}

The increasing incidence of immigration and information-seeking behaviour of medical doctors in north-western Greece

\section{AUTHORS}

Xenophon Bazoukis ${ }^{1} \mathrm{MD}, \mathrm{MSc}$ *

Nicolaos Kalampokis ${ }^{2} \mathrm{MD}$

Alexandra Papoudou-Bai ${ }^{3}$ MD, PhD

George Bazoukis ${ }^{4}$ MD, MSc

Nikolaos Grivas ${ }^{5}$ MD, PhD

\section{CORRESPONDENCE}

*Dr Xenophon Bazoukis xbazoukis@gmail.com

\section{AFFILIATIONS}

1, 2, 5 Department of Urology, G. Hatzikosta General Hospital, Ioannina, Greece

${ }^{3}$ Department of Pathology, Faculty of Medicine, School of Health Sciences, University of loannina, Greece

${ }^{4}$ Department of Cardiology, General Hospital of Athens "Evangelismos", Athens, Greece

\section{PUBLISHED}

23 March 2020 Volume 20 Issue 1

\section{HISTORY}

RECEIVED: 6 April 2018

REVISED: 30 January 2020

ACCEPTED: 1 March 2020

\section{CITATION}

Bazoukis X, Kalampokis N, Papoudou-Bai A, Bazoukis G, Grivas N. The increasing incidence of immigration and information-seeking behaviour of medical doctors in north-western Greece. Rural and Remote Health 2020; 20: 4877. https://doi.org/10.22605/RRH4877

This work is licensed under a Creative Commons Attribution 4.0 International Licence

\section{ABSTRACT:}

Introduction: Brain drain, an increasing phenomenon, can be defined as the international transfer of resources, in the form of a highly educated workforce, from developing to more developed countries. The tendency for migration leads to the activation of informational behaviour. The aim of this study was to search for the main causes of emigration of Greek medical doctors while their country suffers from an economic crisis.
Methods: A cross-sectional study using a quantitative sampling method in the form of questionnaires was performed. These questionnaires were answered by 143 doctors working in the National Health System in the city of loannina in north-western Greece. Correlations between the examined parameters and predictive factors of immigration trend were recorded.

Results: A total of $85 \%$ of the respondents were dissatisfied with 
their wage, only $30 \%$ were sure that they would keep their current job and nearly $52 \%$ of them answered negatively to questions regarding their professional development. Only 33\% of the physicians were negatively disposed towards moving abroad. Most of them were permanent personnel. Unsatisfactory wages, job uncertainty, non-permanent working status and low professional development opportunities were correlated with the phenomenon of immigration (all $p<0.001$ ). In the multivariate binary logistic regression analysis, lower wage (odds ratio $(O R)=0.66,95 \%$ confidence interval $(\mathrm{Cl})=0.453-0.961, p=0.03)$ and job uncertainty $(\mathrm{OR}=1.355,95 \% \mathrm{Cl}=1.040-1.767, p=0.025)$ were independent predictors of the immigration trend.

Conclusion: The tendency of Greek medical doctors to emigrate is strongly related to financial dissatisfaction, professional insecurity and minimal development opportunities. Especially in rural areas these high immigration trends can result in a shortage of GPs. The need for emigration is less common among qualified doctors with permanent contracts.

\section{Keywords:}

brain drain, financial crisis, Greece, immigration, informational behaviour, medical doctors.

\section{FULL ARTICLE:}

\section{Introduction}

During the 1950s and 1960s, Greece experienced the greatest, until that time, wave of emigration. A great number of people, especially unskilled workers, sought better working and living conditions by moving to countries that promised a better quality of life. In contrast, the modern emigrants of Greece are young, ambitious, talented and highly educated people ${ }^{\mathbf{1}}$. The current emigration phenomenon, also known as 'brain drain', can be defined as the international transfer of resources, in the form of a highly educated workforce, from developing to more developed countries ${ }^{2}$. A total of $23-28 \%$ of the doctors in the USA, the UK, Canada and Australia come from countries with lower salaries ${ }^{3}$. Overall, these countries provide $40-70 \%$ of the international medical graduates ${ }^{4}$.

The Greek healthcare system has seriously been affected by a restricted policy forced by the institutions that have loaned money to Greece during the economic crisis (European Union, International Monetary Fund and the Central European Bank). Public expenditure on health care should not exceed $6 \%$ of gross domestic product (GDP); therefore, there has been a reduction of $30 \%$ on hospital budgets, a $40 \%$ pay cut for healthcare professional salaries and a $10-40 \%$ loss of staff. In a qualitative study, health professionals reported that working conditions are characterised by a dramatic increase in public hospital admissions, alongside a huge decrease in personnel, lack of consumables and other materials, while at the same time doctors struggle to meet patient needs $\mathbf{5}$.

Another study showed that the prevalences of burnout (emotional exhaustion, depersonalisation, low personal accomplishment) among health employees of three Greek hospitals was approximately $44.5 \%, 43.2 \%$ and $51.5 \%$, respectively. Among medical residents at these hospital, high burnout rates were observed in $56.6 \%, 66.2 \%$ and $58.5 \%$ of them, respectively ${ }^{6}$. Data collected from the Athens Medical Association indicate that the number of Greek doctors emigrating to countries of the European Union has increased dramatically, showing a five-fold increase in 2012 in comparison to 2007, while 4000 doctors had already migrated to a foreign country by 2013 , and $60 \%$ of them were specialist doctors ${ }^{7}$. The migration of highly trained human resources inevitably has a negative impact on the country of origin, mainly due to loss of the capital invested on the education of the graduates and the acquisition of their specialties ${ }^{\mathbf{8}}$.

Some of the most important stimulating factors for doctors based on the present literature include mental challenge, opportunities for professional recognition, sense of responsibility, autonomy, relationships with colleagues, free expression and decisionmaking $\mathbf{9 , 1 0}^{\mathbf{1 0}}$. Information behaviour is defined as the efforts made by a person by any means to retrieve information when he/or she becomes aware of his or her need for information on a subject, either for (direct) use or distribution ${ }^{\mathbf{1 1}}$.

The purpose of the present study was to identify the motivating factors of Greek medical doctors to migrate abroad and to study the correlation between wage, development opportunities, job insecurity and information-seeking behaviour with this phenomenon.

\section{Methods}

The present cross-sectional study used a quantitative sampling method in the form of questionnaires. The questions were scaled from 1 to 5, covering a spectrum of answers from 'I fully disagree' to 'I totally agree'. The first part of the questionnaires covered demographic and labour data, while the second part was concerned with rewards, job insecurity, professional development opportunities and the resulting trend towards migration and information-seeking behaviour among the responding doctors. Approximately 180 questionnaires were distributed from February to April 2017, to physicians from all grades of the National Health System (NHS) and the teaching science staff at the General Hospital 'Hatzikosta' and the University Hospital of Ioannina. The aforementioned hospitals are both considered to be reference centres for the entire region of north-western Greece and accept patients from a large, mainly mountainous and rural area, as well as from the majority of the lonian Islands. A great number of doctors making up the workforce of those hospitals are GPs who have been mobilised from rural health centres to compensate for the lack of specialist doctors in many of the departments of these two hospitals.

The rates of satisfaction, regarding the incentives of medical doctors in their current work, were reflected in responses to the following three statements: 'my financial rewards are satisfactory', 
'compensation includes high pay levels' and 'the increase in my financial rewards is satisfactory ${ }^{\mathbf{1 2}}$. The rates of job insecurity among doctors were reflected in responses to statements such as 'I am very likely to lose my job soon', 'I think I may lose my job in the near future' and 'I feel insecure about the future of my career $^{\mathbf{1 3}}$. The opportunities for professional development were reflected in responses to statements such as 'my work offers evolvement opportunities', 'in my work I have the opportunity to develop the strong points of my personality' and 'in my work I can develop myself sufficiently' ${ }^{\mathbf{1 4}}$. The possibility of emigrating was studied through the statements 'I am most likely to look for a new job outside Greece within the next year' and 'I frequently consider migration as an option ${ }^{\mathbf{1 5}}$.

A factor analysis was performed (Extraction Method: Principal Axis Factoring) by rotating the shafts by 180 degrees (Rotation Method: Promax with Kaiser Normalisation). The reliability of the measuring tools of these variables was tested using the Cronbach's alpha index, which was greater than 0.7 for all variables. The Pearson statistical test was used to examine the correlations between the examined variables. A binary logistic regression analysis was performed to find predictive factors of immigration trend. Odds ratios $(\mathrm{OR})$ and $95 \%$ confidence intervals $(\mathrm{Cl})$ were calculated. To ensure that co-linearity would be prevented, only one question was selected from each of the three questionnaire groups (wage, job uncertainty and opportunities for development). SPSS Statistics v20.0 (IBM; http://www.spss.com) was used.

\section{Ethics approval}

Collection of research data was approved by the Hellenic Republic Ministry of Health (protocol number 7467).

\section{Results}

A total of 143 questionnaires were returned fully answered, corresponding to a response rate of $79.5 \%$. A total of $51 \%$ of the participants were men. In total, $60.1 \%$ of respondents were resident doctors, while $30.8 \%$ were attending physicians and $9.1 \%$ were professors in the Faculty of Medicine of loannina. A total of $72 \%$ of the respondents were doctors without a permanent contract, while $28 \%$ had a permanent contract with the hospital.
Among the respondents, $85 \%$ reported that their wage was unsatisfactory, another $12 \%$ had a more neutral attitude towards this issue and only 3\% described their rewards as rather satisfactory. For the professional security factor, $45 \%$ of respondents reported being certain that they would lose their job, or having a strong feeling of job insecurity, with only a $30 \%$ of the respondents being sure that they would definitely remain in their current job. Responses regarding development opportunities showed that nearly $52 \%$ of respondents answered negatively to questions about their personality's development through their daily routine, while the rest of them responded that they were able to acquire new information regarding their fields of expertise and develop the strong aspects of their personality. Regarding the respondents' answers towards the contemporary tendency to emigrate, $33 \%$ were negatively disposed to that, $41 \%$ considered the possibility of moving abroad for business, with the rest of the respondents being neutral/indifferent (close to average status 3 ) (neither agree nor disagree).

Correlations between the examined variables are presented in Table 1. The variable of wage indicated a strong negative correlation with the trend for emigration $(r=-0.28, p=0.00)$, as well as the frequency of seeking for information on emigration $(r=-0.25, p=0.00)$. Job insecurity was related with increasing trend for emigration and increasing frequency for information search. The parameter of career opportunities had a strong negative correlation with both the trend for emigration $(r=-0.27, p=0.00)$ and the search for information on moving abroad $(r=-0.28$, $p=0.00$ ). Finally, the trend towards migration had a strong positive correlation with the frequency of information seeking $(r=0.71$, $p=0.00)$ and searching through specific sources $(r=0.50 p=0.00)$, as expected. Working status had a strong positive correlation with the sense of job insecurity, the tendency of immigration, the frequency of the search for information on relocation and searches using different sources of information. In the multivariate binary logistic regression analysis, lower wage $(\mathrm{OR}=0.66,95 \% \mathrm{Cl}=0.453-0.961, p=0.03)$ and job uncertainty $(\mathrm{OR}=1.355,95 \% \mathrm{Cl}=1.040-1.767, p=0.025)$ were independent predictors of the emigration trend.

Table 1: Correlations between examined parameters related to emigration

\begin{tabular}{|c|c|c|c|c|c|c|c|}
\hline & \multirow{3}{*}{$\begin{array}{l}\text { Wage } \\
0.08 \\
\end{array}$} & \multirow[b]{2}{*}{$\begin{array}{c}\text { Job } \\
\text { uncertainty }\end{array}$} & \multirow{2}{*}{$\begin{array}{c}\begin{array}{l}\text { Development } \\
\text { opportunities }\end{array} \\
-0.09\end{array}$} & \multirow{3}{*}{$\begin{array}{c}\begin{array}{c}\text { Immigration } \\
\text { tendency }\end{array} \\
0.39^{\star}\end{array}$} & \multirow{2}{*}{$\begin{array}{c}\text { Frequency } \\
\text { of } \\
\text { information } \\
\text { seeking }\end{array}$} & \multirow[b]{2}{*}{$\begin{array}{l}\text { Search in } \\
\text { specific } \\
\text { sources }\end{array}$} \\
\hline & & & & & & & \\
\hline $\begin{array}{l}\text { Working } \\
\text { status }\end{array}$ & $\begin{array}{l}\text { Pearson } \\
\text { Correlation } \\
\text { Sig. (2-tailed) }\end{array}$ & & $\begin{array}{l}0.53^{*} \\
0.00^{\star}\end{array}$ & $\begin{array}{c}-0.09 \\
0.29\end{array}$ & & $\begin{array}{l}0.33^{\star} \\
0.00^{\star}\end{array}$ & $\begin{array}{l}0.37^{\star} \\
0.00^{\star}\end{array}$ \\
\hline Wage & $\begin{array}{l}\text { Pearson } \\
\text { Correlation } \\
\text { Sig. (2-tailed) }\end{array}$ & 1 & $\begin{array}{l}-0.16 \\
0.06\end{array}$ & $\begin{array}{l}0.13 \\
0.14 \\
\end{array}$ & $\begin{array}{l}-0.28^{*} \\
0.00^{\star}\end{array}$ & $\begin{array}{l}-0.25^{\star} \\
0.00^{\star}\end{array}$ & $\begin{array}{c}-0.12 \\
0.14 \\
\end{array}$ \\
\hline $\begin{array}{l}\text { Job } \\
\text { uncertainty }\end{array}$ & $\begin{array}{l}\text { Pearson } \\
\text { Correlation } \\
\text { Sig. (2-tailed) }\end{array}$ & & 1 & $\begin{array}{l}-0.10 \\
0.25\end{array}$ & $\begin{array}{l}0.39^{*} \\
0.00^{\star}\end{array}$ & $\begin{array}{l}0.33^{\star} \\
0.00^{\star}\end{array}$ & $\begin{array}{l}0.28^{*} \\
0.00^{*}\end{array}$ \\
\hline $\begin{array}{l}\text { Development } \\
\text { opportunities }\end{array}$ & $\begin{array}{l}\text { Pearson } \\
\text { Correlation } \\
\text { Sig. (2-tailed) }\end{array}$ & & & 1 & $\begin{array}{l}-0.27^{*} \\
0.00^{\star}\end{array}$ & $\begin{array}{l}-0.28^{*} \\
0.00^{\star}\end{array}$ & $\begin{array}{l}-0.17 \\
0.04\end{array}$ \\
\hline $\begin{array}{l}\text { Immigration } \\
\text { tendency }\end{array}$ & $\begin{array}{l}\text { Pearson } \\
\text { Correlation } \\
\text { Sig. (2-tailed) }\end{array}$ & & & & 1 & $\begin{array}{l}0.71^{\star} \\
0.00^{\star}\end{array}$ & $\begin{array}{l}0.50^{\star} \\
0.00^{*}\end{array}$ \\
\hline
\end{tabular}

Strong correlation 


\section{Discussion}

This study was performed in two hospitals that serve as reference centres in north-western Greece. It can be inferred that experienced and skilled doctors who belong to the permanent personnel of the hospitals experience lower levels of insecurity feelings regarding their professional future since they occupy permanent posts, with higher rates of professional development opportunities. Their frequencies of emigrating and seeking information on working and living conditions abroad are lower.

Upon processing the variable of satisfaction resulting from each doctor's reward, a negative correlation was found. The frequency of information searching about emigration appears to be higher among the medical population with lower incomes. These results were introduced in accordance with some financial theories, which state that both economic and non-economic factors are responsible for the stampede of scientists towards foreign countries $^{\mathbf{1 6}}$. Research indicates that the economic crisis and the reduction in the income have an impact on the performance of Greek physicians $\mathbf{1 7}^{\mathbf{1 7}}$ while in a study including only doctors working in Greek hospitals, the factor of wage satisfaction occupied the second position in a descending order of importance ${ }^{\mathbf{1 8}}$.

A highly strong correlation with the trend towards emigration was indicated while analysing the work insecurity variable. This correlation is evidence of the fact that, as long as feelings of work insecurity increase, both the tendency for immigration and the frequency of seeking information will continue to increase. It is indicative that the lack of medical personnel in public hospitals has led to repeated requests by the European Commission in Greece to ensure full compliance with EU rules in relation to working time limits for doctors in public health services; in many cases, doctors have to work more than 90 hours per week ${ }^{\mathbf{1 9}}$. According to another study, during the economic crisis, there has been an increase in the number of patients examined in public hospitals by $24 \%$ in 2010 compared to the previous year, while there was an additional increase of $8 \%$ in $2011^{20}$. Since 2011, the continual reduction in budgets has led to decreased job opportunities in universities and public hospitals $\mathbf{2 0}^{\mathbf{2 0}}$. This is an additional factor that amplifies the migration trend and leads even more young doctors to seek employment opportunities abroad $\mathbf{1}$.

There is a strong negative correlation between development opportunities in the medical profession and the trend towards migration and information search. This means that as long as the sense of development in the workplace remains unsatisfactory, the trend of medical migration and the search for information and vacancies abroad will continue to increase. In another study, it was reported that employees are more likely to abandon their field of expertise and follow a different career path when their skills are not developed properly, or when superiors are not interested in the career progression of their employees ${ }^{\mathbf{2 1}}$. A study in Greek hospitals indicated that personal recognition, related to factors such as development opportunities, is a major motivating force in the working environment ${ }^{\mathbf{1 8}}$.

A motivating factor is crucial for an individual to want to acquire new information relating to professional development. This need for information will manage or fail to be satisfied through a process including personal, social and environmental obstacles. The behaviour of individuals as information recipients is involved, as well as the communication of media providers ${ }^{\mathbf{1 1}}$. The theories that have already been mentioned on information behaviour are in accordance with the results of the present study that increase in emigration is related to the search for information by various means.

The present study had some limitations. First, the survey was conducted locally, so there is a lack of generalisability in results. As far as the sample of the survey is concerned, the number of respondents can be considered satisfactory. However, there is a relative heterogeneity in the quality of the respondents in terms of status. The number of resident doctors who responded was significantly higher than that of attending physicians with a permanent working status. Perhaps there could be a relative differentiation if research was conducted in a larger sample with equal numbers of resident and qualified doctors. Furthermore, this study was influenced by certain limitations due to the method of data collection using self-referencing questionnaires, which is considered to be the most widespread and suitable method for the examination of such variables. As a result, there is an information bias due to the close type of the answers given. In addition, a certain limitation of the method is the data's chronically static status, as the questionnaires report the trend of a specific narrow time lapse. Also to be considered is that the nature of the questions may have provoked unpleasant feelings in the physicians, as it is difficult for them to admit the arduous position of their incomes, job insecurity and low possibilities for professional development.

Finally, it should be noted that the study took place in the region of Epirus, a rural area of western Greece situated approximately 5 hours drive from the capital of the country (Athens). Until recently, before the construction of modern roads, loannina was 8 hours drive from the biggest cities of Greece, namely Athens and Thessaloniki. Moreover, due to the distinct geomorphology of the region, approximately 16 rural health centres belong to the prefecture of loannina. Too many GPs from those health centres are asked to work at the hospitals, most days of the week, to cover the needs of several medical departments, because of the aforementioned lack of specialist personnel. This action inevitably causes lack of GPs in rural areas and poor primary health care for the citizens. Furthermore, the high salaries in English-speaking countries have resulted in many of the GPs doing locum work in those countries, and turning their back on the Greek National Health Service, making the situation even worse.

Further research needs to be conducted to be able to compare properly the emigration and information-seeking behaviour of medical doctors living in rural and large urban areas.

\section{Conclusions}

Income dissatisfaction and job insecurity showed a strong positive correlation with the trend for emigration, as well as the frequency 
of searching for information on migration. Satisfactory professional opportunities were found to be an inhibiting factor. The need for immigration is less apparent among qualified doctors with permanent contracts, many years of professional experience and greater development opportunities, with financial satisfaction remaining a significant issue for them as well. Finally, rural areas are also affected by brain drain, struggling to keep the primary healthcare doctors in place, since many of them are transferred to work in hospitals or choose to move abroad for a better future for them and their families.

\section{Acknowledgements}

The authors are grateful to Assistant Professor P. Gorezis, who provided insight, expertise and comments that substantially assisted this research.

\section{REFERENCES:}

1 Ifanti A, Argyriou A, Kalofonou F, Kalofonos H. Physicians' brain drain in Greece: a perspective on the reasons why and how to address it. Health Policy 2014; 117(2): 210-215. https://doi.org /10.1016/j.healthpol.2014.03.014 PMid:24794987

2 Beine M, Docquier F, Rapoport H. Brain drain and human capital formation in developing countries: winners and losers. The Economic Journal 2008; 118(528): 631-652. https://doi.org /10.1111/j.1468-0297.2008.02135.x

3 Kangasniemi M, Winters A, Commander S. Is the medical brain drain beneficial? Evidence from overseas doctors in the UK. Social Science \& Medicine 2007; 65: 915-923. https://doi.org/10.1016 /j.socscimed.2007.04.021 PMid:17570573

4 Okeke E. Brain drain: do economic conditions 'push' doctors out of developing countries? Social Science \& Medicine 2013; 98: 169-178. https://doi.org/10.1016/j.socscimed.2013.09.010 PMid:24331896

5 Kerasidou A, Kingori P, Legido-Quigley H. You have to keep fighting: maintaining healthcare services and professionalism on the frontline of austerity in Greece. International Journal for Equity in Health 2016; 15: 118. https://doi.org/10.1186 /s12939-016-0407-8 PMid:27457098

6 Rachiotis G, Kourousis C, Kamilaraki M, Symvoulakis E, Dounias G, Hadjichristodoulou C. Medical supplies shortages and burnout among Greek healthcare workers during economic crisis: a pilot study. International Journal of Medical Sciences 2014; 11(5): 442-447. https://doi.org/10.7150/ijms.7933 PMid:24688306

7 Medical Association of Athens. Report of Athens Medical Association. [In Greek]. 2013. Available: http://www.isathens.gr /syllogos/arxeio-drasewn-isa/arxeio-syndikalistiko/ (Accessed 2 January 2017).

8 The mutually reinforcing relation between international migration of highly educated labour force and economic crisis: the case of Greece. Southeast European Black Sea Studies 2013; 13(4): 525-551. https://doi.org/10.1080/14683857.2013.859814

9 What motivates physicians throughout their careers in medicine? Comprehensive Therapy 2006; 32: 210-217. https://doi.org/10.1007 /BF02698065 PMid:17918306

10 Tsounis A, Sarafis P, Bamidis P. Motivation among physicians in Greek public health-care sector. British Journal of Medicine \& Medical Research 2014; 4(5): 1094-1105. https://doi.org/10.9734 /BJMMR/2014/6821
11 Wilson T. Models in information behavior research. Journal of Documentation 1999; 55(3): 249-270. https://doi.org/10.1108 /EUM0000000007145

12 Spreitzer G. Psychological empowerment in the workplace: dimensions, measurement and validation. Academy of Management Review 1995; 38(5): 1442-1465. https://doi.org $/ 10.5465 / 256865$

13 Feather N, Rauter K. Organizational citizenship behaviors in relation to job status, job insecurity, organizational commitment and identification, job satisfaction and work values. Journal of Occupational and Organizational Psychology 2004; 77(1): 81-94. https://doi.org/10.1348/096317904322915928

14 Bakker A, Demerouti E, De Boer E, Schaufeli W. Job demands and job resources as predictors of absence duration and frequency. Journal of Vocational Behavior 2003; 62: 341-356. https://doi.org/10.1016/S0001-8791(02)00030-1

15 Cammann C, Fichman M, Jenkins D, Klesh R. Assessing the attitudes and perceptions of organizational members. In: SE Seashore, EE Lawler, PH Mirvis, C Cammann (Eds). Assessing organizational change. New York: John Wiley and Sons, 1983.

16 King R. Return migration. Area 1978; 10(3): 175-182. https://doi.org/10.1007/BF02917864

17 Saridi M, Karra A, Souliotis K. Work related stress in health care professionals in the economic crisis. General Archives of Hellenic Medicine 2016; 33(1): 73-83.

18 Kontodimopoulos N, Paleologou V, Niakas D. Identifying motivational factors for professionals in Greek hospitals. BMC Health Services Research 2009; 9: 164. https://doi.org/10.1186 /1472-6963-9-164 PMid:19754968

19 European Commission. Working time: Commission requests Ireland and Greece to comply with the EU rules on limits to working time in public health services. 2011. Available: http://europa.eu/rapid/press-releaselP-11-1121 (Accessed 25 May 2017).

20 Trachana V. Austerity-led brain drain is killing Greek science. Nature 2013; 496(7445): 271. https://doi.org/10.1038/496271a PMid:23598305

21 Hay M. Strategies for survival in the war of talent. Career Development International 2002; 7(1): 52-55. https://doi.org /10.1108/13620430210414883 
This PDF has been produced for your convenience. Always refer to the live site https://www.rrh.org.au/journal/article/4877 for the Version of Record. 